\title{
Market power analysis of the Indian power market
}

\author{
Aniket Raj ${ }^{1 *}$, Utkarsh Gupta ${ }^{2 *}$, Prabhakar Tiwari ${ }^{3}$, Asheesh K Singh ${ }^{4}$ \\ ${ }^{1 *}$ Department of Electrical Engineering, MMM University of Technology, U.P. India \\ ${ }^{2 *}$ Department of Electrical Engineering, MMM University of Technology, U.P. India \\ ${ }^{3}$ Department of Electrical Engineering, MMM University of Technology, U.P. India \\ ${ }^{4}$ Department of Electrical Engineering, MNNIT, Allahabad, India \\ "Corresponding Author: e-mail: a.rajresearch@gmail.com,Tel+91-8736030407
}

\begin{abstract}
Emerging electricity reforms in the power market aims at removing the monopolistic oligopoly power market and promoting competition in the market by providing opportunities to more producers. This paper seeks to investigate various existing structures of the Power Market. Indian Energy Exchange (IEX) and Power Exchange India Limited (PXIL) facilitates transparent trading of electricity, a larger market spectrum and allows the participation of other players in the market. Market power is an indicator of an non-competitive market, that is increase in the market power will result in the degradation of competition. This research will help modify the current parameters (HHI Index and Concentration ratio) which are used for measuring the market power of the power markets. As there is always deviation in unconstrained cleared volume and actual cleared or scheduled volume, deviation arises due to the volume of electricity that could not be cleared because of congestion in the power exchange. The researchers have also examined the Indian Power market and analyzed different developed power markets of the world like the US Pennsylvania-New Jersey-Maryland Interconnection (PJM) and the Nordpool.
\end{abstract}

Keywords: Market Power, Scheduled Power, Power Market, Herfindahl-Hirschman Index (HHI), Concentration Ratio.

DOI: http://dx.doi.org/10.4314/ijest.v13i1.6S

Cite this article as:

Raj A., Gupta U., Tiwari P., Singh A.K. 2021. Market power analysis of the Indian power market, International Journal of Engineering, Science and Technology, Vol. 13, No. 1, pp. 39-47. doi: 10.4314/ijest.v13i1.6S

Received: December 1, 2019; Accepted: February 5, 2021; Final acceptance in revised form: March 31, 2021

This paper was earlier presented at the International Conference on Energy, Environment \& Material Sciences (ICE2M), 1-3 December 2019 and substantially improved for this Special Issue. Guest Editor: Dr. Sri Niwas Singh, Professor (HAG), Department of Electrical Engineering, Indian Institute of Technology Kanpur, 208016 (U.P.) India, former Vice-Chancellor, Madan Mohan Malviya University of Technology Gorakhpur (April 2017 to July 2020).

\section{Introduction}

The conventional electric power sector had mainly three fundamental building blocks- Generation, Transmission and Distribution. Traditionally, all three firms were operated together and such type of firm is referred to as a "vertically integrated" firm. Nowadays, these vertically integrated firms have been replaced with the Independent Power Producers- IPP and as of now, all three blocks are operating independently. In the current scenario, the government is seeking the investment of the private sector into the power market which will encourage competition in the market along with making the market more efficient. The installed generating capacity shrank down in the public sector, while there is rapid growth from $15 \%$ to $45 \%$ is observed in the private sector. The shares of the state and central sectors are decreased by $24 \%$ and 14\% respectively from 2008-2018 (CERC Report, 2017-18). 
Market structure refers to the characteristic of the market and it defines the competition for various goods in the market. According to World Bank's report, there is a significant role of the design of market structure for the initialization of reform in the power sector that has a major effect in decision-making, structure of contracts, and decisions related to the price of goods. The number of buyers and the number of sellers are the two determinants of the market structure and their concentration mainly matters.

Table 1. Different Market Structures (MHRD, NME-ICT)

\begin{tabular}{|l|l|l|l|}
\hline \multirow{2}{*}{\multicolumn{1}{c|}{ Market Structures }} & \multicolumn{2}{c|}{ Criteria } & \multicolumn{1}{c|}{ Competition } \\
\cline { 2 - 4 } & \multicolumn{1}{c|}{ Number of Sellers } & Barriers to Entry & High \\
\hline Perfect Competition & Very Large & Relatively Low & Limited \\
\hline Monopolistic Competition & Many & High & High Interdependence \\
\hline Oligopoly & Few & Very High & No \\
\hline Monopoly & One Dominant & &
\end{tabular}

In a perfectly competitive market, market power tends to zero. Various initiatives have been taken to reduce market power since the increase in the market power will promote the monopolistic power market. There are various explanations for the term Market Power. In general, Market Power is defined as the ability of a firm to manipulate the price of an item. By exercising market power, suppliers of the market will become price manipulator that is the price maker, not a price taker(Khan et.al, 2015). The Electricity Act 2003 came into existence intending to promote healthy competition in the electricity market in India. This act also enabled the participation of private players into the generation segment by promoting a license-free administration and regime. As a result, the power sector's competition increased significantly and the theft of electricity is also reduced. The rapid increase in the population emphasis the government of India to take several steps for the upliftment of the electric power sector. Many new schemes came into existence which influenced the participation of the private sector in the field of the power market. Short term market trade increases to provide flexibility in the market, the number of traders in the short-term market who were undertaking to trade through exchanges has increased from 14 to 28 in ten years. In India, 89\% of the total power traded through long-term contracts and the remaining $11 \%$ is traded through the short-term market.

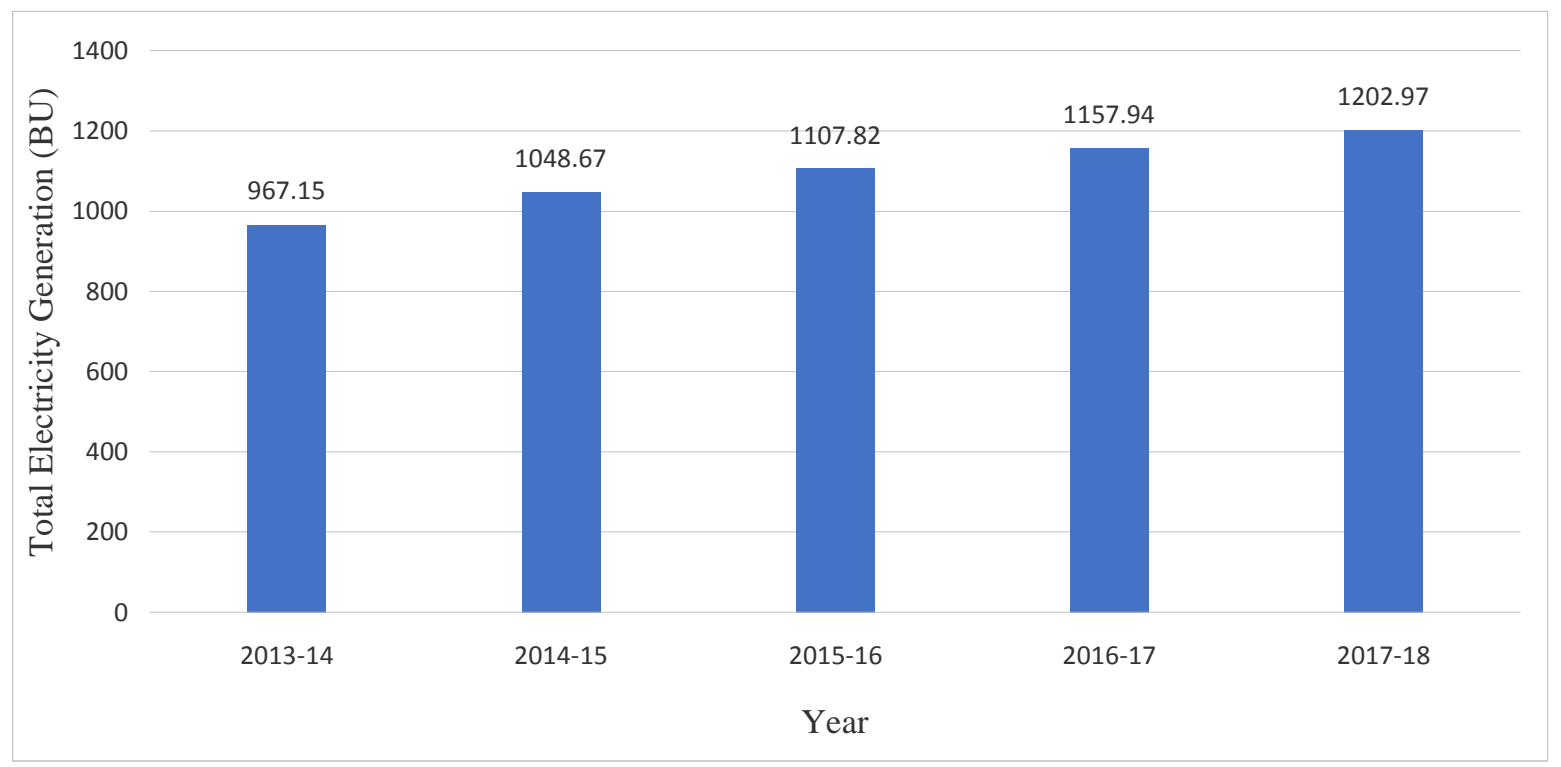

Fig. 1. Yearly Data on Total Electricity Generation (Short-Term Report, CERC 2017-18)

This study is organized as follows; Section 2 is the case study of the Electricity Market in India. Section 3 discusses various parameters for measuring market power like the HHI and Concentration Ratio. Section 4 discusses the modification in the formulation used for the estimation of market power. Section 5 discusses the comparison of the Indian power market with various developed Power markets of the world.

\section{Case Study: Indian Power Market}

Today, India is the third-largest electricity consumer in the world. The increasing demand for electricity is a result of a growing population. To meet this demand government of India has taken various initiatives including missions like Saubhagya, Uday, and Rural Electrification, etc. Despite many challenges, India is also ranked as the third-largest producer of electricity. The shortage of 
energy decreased from $11.1 \%$ in 2008-09 to about $0.7 \%$ in 2017-18(Short-Term Report, CERC 2017-18). The increasing demand for electricity is one of the reasons for promoting competition in the market so that the consumers can get power at a relevant price.

Table 2. Power Supply Positions in India (Short-Term Report, CERC 2017-18)

\begin{tabular}{llll}
\hline & \multicolumn{3}{c}{ Energy (BU) } \\
\cline { 2 - 4 } Year & Requirement & Availability & Deficit \\
\hline $2013-14$ & 1002.26 & 959.83 & $4.2 \%$ \\
$2014-15$ & 1068.92 & 1030.79 & $3.6 \%$ \\
$2015-16$ & 1114.41 & 1090.85 & $2.1 \%$ \\
$2016-17$ & 1142.93 & 1135.33 & $0.7 \%$ \\
$2017-18$ & 1212.13 & 1203.57 & $0.7 \%$
\end{tabular}

Table 2 shows the yearly data of available energy, required energy, and deficit percentage. As a result, the effort for increasing generation capacity, the available energy has increased. In this way, the deficit percentage has been decreased.

\subsection{Power Exchange and Availability Based Tariff (ABT)}

In 2008, IEX and PXIL have been established to promote transparent trading of electricity, a larger market spectrum and allows the participation of other players in the market. One major step in the development of the Indian power market is the enactment and execution of Availability Based Tariff (ABT) which implemented effective day-ahead scheduling and frequency sensitive charges for the deviation from the schedule for more efficient real-time balancing(CERC, 2017-18). In ABT based pricing scheme a generating station will be paid by summing the amount of capacity charge, energy charge, and unscheduled power interchange penalty. A fixed charge or Capacity charge is a monthly imposed charge on each beneficiary according to their authorized power from the generating station. Variable charge or Energy charge is the cost of fuel used for power generation, operating charge, etc. Unscheduled Interchange charge (UIC), is a charge to be paid by the beneficiary for the deviation from the scheduled power.

$$
\mathrm{UI}=\text { Actual Energy }- \text { Scheduled Energy }
$$

In the above expression, if UI comes to be positive the monetary incentive will be given and if the UI is negative penalty will be imposed as per the price regulated by Central Electricity Regulatory Authority (CERC). The UI penalty is imposed on the beneficiary based on the average grid frequency of the 15-minute time block.

\subsection{Power Market Composition}

The ownership structure of the Indian Power market includes the participation of state, central, and private sectors. Fig. 2 shows the ownership structure of the Indian Power market as of 31 May 2019. There is an increment in the percentage of the private sector in the power market, which has promoted the competition in the Wholesale Electricity Market of India(WEMI).

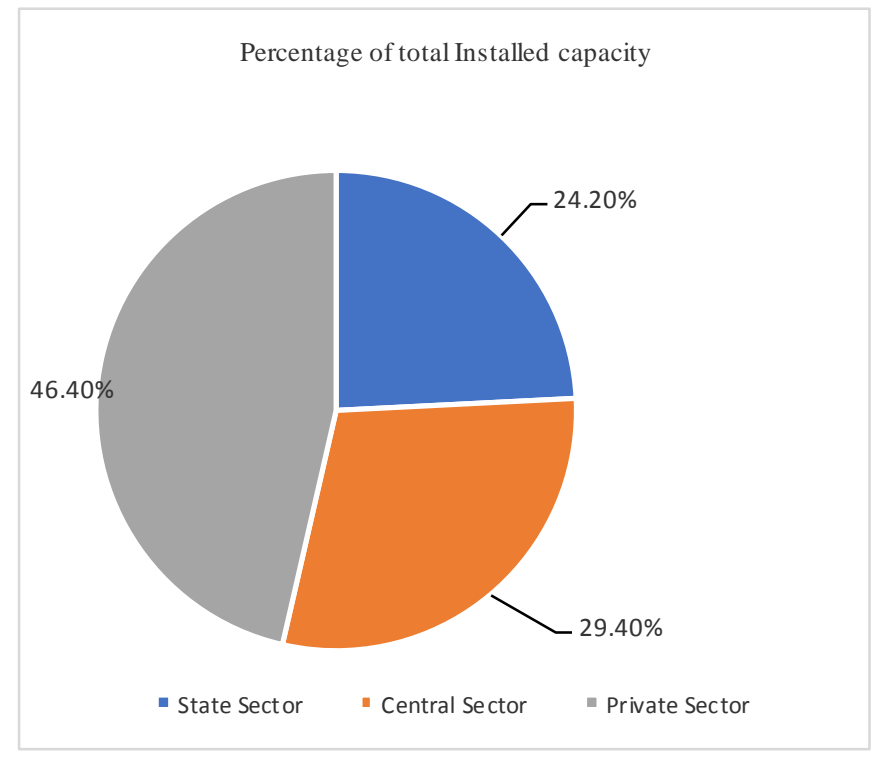

Fig. 2. Share of sectors in total installed capacity (Ministry of Power, GOI 2019) 


\subsection{Installed Capacity and its Sources}

Installed Power refers to the summation of nominal powers of all power-consuming devices in the installation. In this section, various sources for the generation of power has been discussed along with their percentages of contribution to total installed generation capacity. Figure 3 shows the percentage contribution of various resources in the installed power generation as of 30 June 2019. The thermal (coal, lignite, gas, diesel) based power generation is the topmost contributor in the installed capacity. Also, the Renewable Energy Source (RES) has a significant contribution to power generation. Table 3 shows the growth of gross electricity generation and the declining electricity import from Bhutan. In the period of five years (2013-18), the production of power from renewable sources has become approximately two folded.

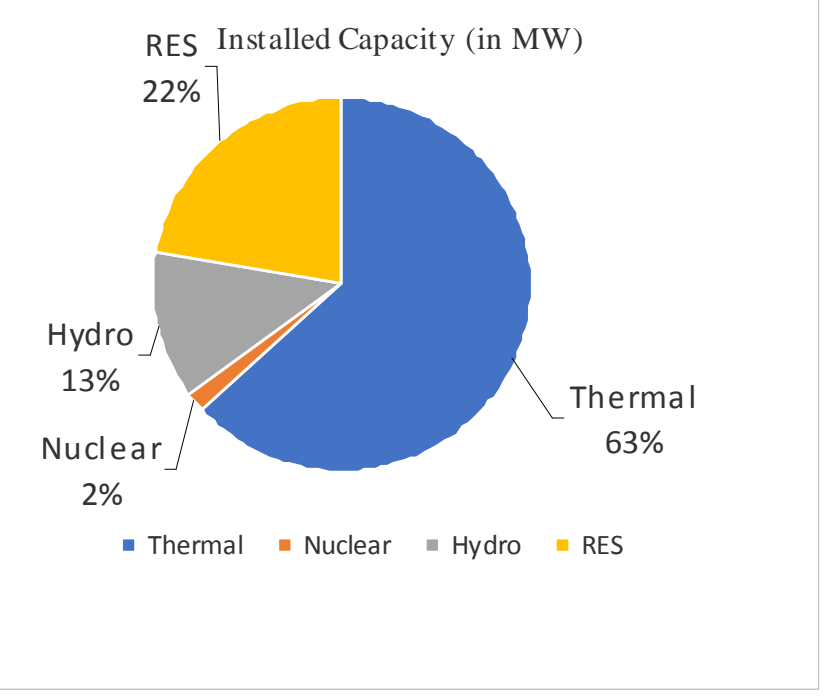

Fig. 3. Various Sources of Power Generation (CERC 2019)

Table 3. Gross Electricity Generation in India (CERC 2017-18)

\begin{tabular}{|l|l|l|l|l|l|l|}
\hline \multirow{2}{*}{ Year } & \multicolumn{6}{|c|}{ Energy (BU) } \\
\cline { 2 - 7 } & $\begin{array}{l}\text { Thermal } \\
\text { Power }\end{array}$ & $\begin{array}{l}\text { Hydro } \\
\text { Power }\end{array}$ & $\begin{array}{l}\text { Nuclear } \\
\text { Power }\end{array}$ & $\begin{array}{l}\text { RES } \\
\text { Import } \\
\text { from } \\
\text { Bhutan }\end{array}$ & $\begin{array}{l}\text { Total } \\
\text { Generation }\end{array}$ \\
\hline $2013-14$ & 792.05 & 134.85 & 34.23 & 59.62 & 5.60 & 1026.34 \\
\hline $2014-15$ & 877.94 & 129.24 & 36.10 & 61.79 & 5.00 & 1110.07 \\
\hline $2015-16$ & 943.01 & 121.38 & 37.41 & 65.78 & 5.20 & 1172.78 \\
\hline $2016-17$ & 994.22 & 122.31 & 37.66 & 81.87 & 5.64 & 1241.70 \\
\hline
\end{tabular}

\section{Dynamic Approach for Estimating Market Power}

The potentiality of a participant in the market to profitably sustain the prices above the competitive level for a notable period is referred to as the Market Power (Kumar et al., 2001). Market Power is one of the major inefficiencies of electricity restructuring and privatization (Asgari et al., 2008). Also, market power is an indicator of an non-competitive market, i.e. an increase in the market power will result in the degradation of competition. Various occurrences of misusing market power in the operation of power markets include the case of the wholesale electricity market of California in 1998, the Midwest US market in June 1998, and the National Electricity Market of Australia in November 1997 (Zammit, 1999). Here, this paper describes two major parameters to measure the market power are Concentration ratio and HHI.

\subsection{Concentration Ratio}

It was postulated that market power should be positively associated with the seller's concentration. This was the common method used to calculate the market power from the shares of the top four or top eight firms. There will be a significant effect on the potentiality of exercising market power if the percentage of the largest market share is above 20\% (Twomey et al., 2004). The concentration ratio (CR4) for the top four firms and concentration ratio (CR8) for the top eight firms is evaluated by adding the shares of the top four and eight firms respectively.

$$
\mathrm{CR} 4=\sum_{i=1}^{4} S_{i}
$$




$$
\mathrm{CR} 8=\sum_{i=1}^{8} S_{i}
$$

where $\mathrm{Si}$ is the market share of the ith firm.

Determining market power from the concentration ratio. Firstly, considering the shares of the top four firms-

$$
\mathrm{CR} 4=\mathrm{S}_{1}+\mathrm{S}_{2}+\mathrm{S}_{3}+\mathrm{S}_{4}
$$

$$
\text { But CR4 }=0.367+0.1027+0.0955+0.0911=0.6653
$$

Secondly, considering the shares of the top eight firms-

$$
\mathrm{CR} 8=\mathrm{S}_{1}+\mathrm{S}_{2}+\mathrm{S}_{3}+\ldots+\mathrm{S}_{8}
$$

$$
\text { But CR8 }=0.367+0.1027+0.0955+\ldots+0.0425=0.877
$$

The concentration ratio for the top four and top eight firms are 0.6653 and 0.8877 . According to DOJ Merger Guidelines 1982, this formulation implies that companies in more concentrated industries were more likely to be exercising market power. Concentration ratio does not consider the firms beyond the top four, and it disregards the relative distribution among the top four firms. Due to these limitations, the HHI is more preferred in calculating market power.

\subsection{Herfindahl-Hirschman Index (HHI)}

HHI is a statistical parameter that is frequently used to measure the degree of ownership concentration among market participants in a proper market (Yang et.al, 2000). HHI is calculated by adding the squares of the market share of all the firms in the industry.

$$
\mathrm{HHI}=\sum_{i=1}^{n} q_{s i}^{2}
$$

where $\mathrm{q}_{\mathrm{si}}$ is the market share of the ith firm and $\mathrm{n}$ is the total number of firms in the market

If, $\mathrm{HHI}=1$ (depicts the monopoly in the market)

$\mathrm{HHI}=0$ (depicts the perfectly competitive market)

$\mathrm{HHI}<0.2$ (diluted oligopoly market)

In India, HHI is the most preferred and reliable criteria to determine the concentration of market power. The increase in the HHI depicts the increase in market power and decrease in competition. Since 1982, this parameter is the benchmark index of the US Justice Department merger guidelines which can be calculated very easily (Rhoades 1995). According to the report published by the Central Electricity Regulatory Commission on 'Short Term Power Market in India 2017-18 in past ten years, the HHI for the Indian power market declined from 0.24 to 0.18 . This decline indicates the decentralization in the market power and growth in competition.

Now, calculating HHI for the Indian Power market based on the above table data. Data of other remaining firms is available on CERC Annual Report for Short Term market.

$$
\begin{aligned}
& \mathrm{HHI}=\sum_{i=1}^{28} q_{s i}^{2} \\
& \mathrm{HHI}=\mathrm{q} 2 \mathrm{~s} 1+\mathrm{q} 2 \mathrm{~s} 2+\mathrm{q} 2 \mathrm{~s} 3+\ldots \ldots+\mathrm{q} 2 \mathrm{~s} 28
\end{aligned}
$$

But HHI $=0.37602+0.10272+0.09552+\ldots \ldots+0.0000012=\mathbf{0 . 1 8 4}$

Since the $H H I<0.2$ the Indian power market is of diluted oligopolistic nature with moderate competition. 


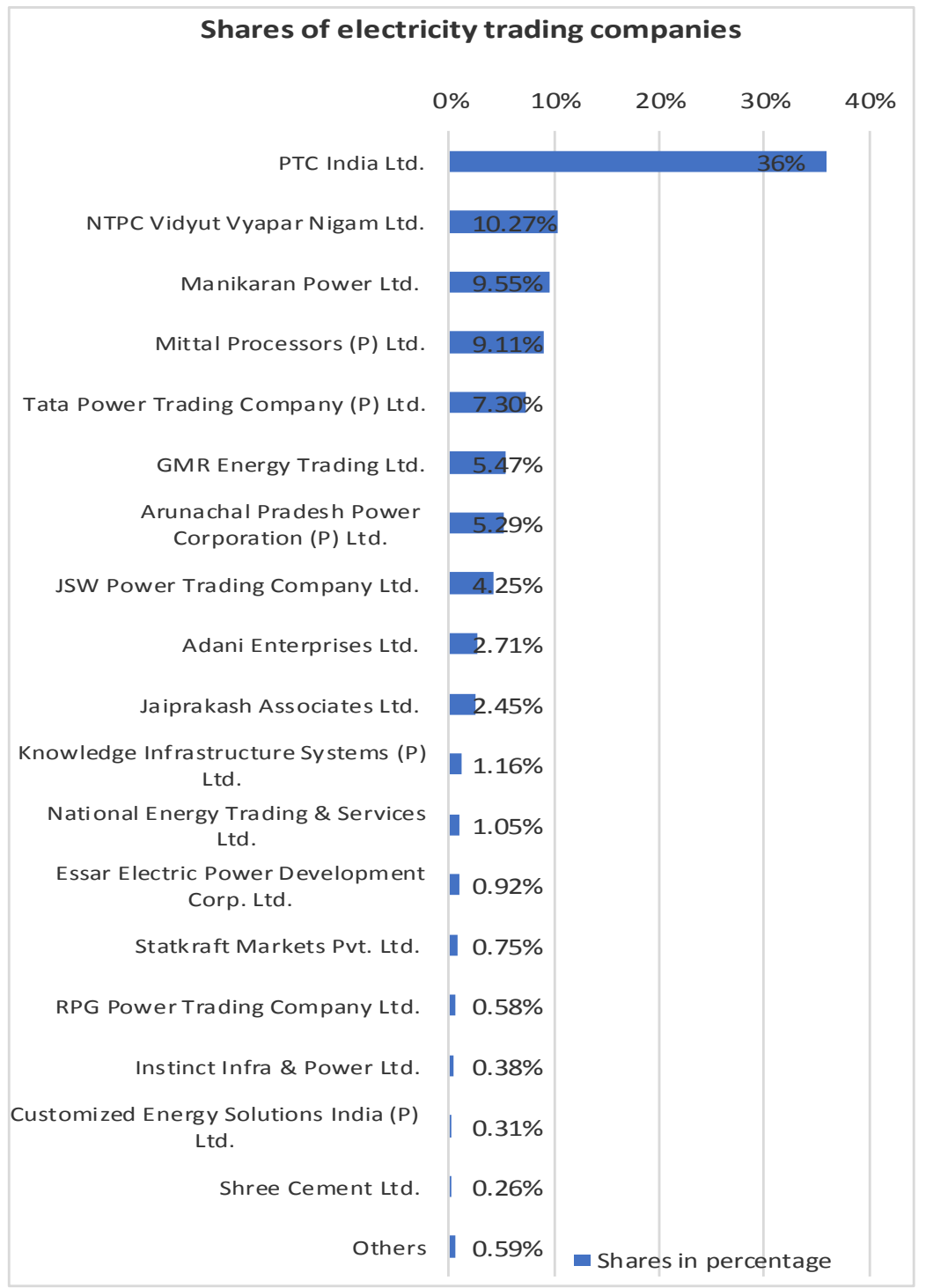

Fig. 4. Electricity Transacted by traders in 2017-18 (CERC 2017-18)

Conventionally, the Herfindahl-Hirschman Index (HHI) for power markets is calculated based on the installed capacity. Furthermore, the short-term demand in the power market is immensely elastic so, it is actual production that should be counted for market power instead of the installed capacity (Cherneko, 2015). Also, it does not depict the impact of market power over the prices in the market. Congestion in the network occurs whenever the transmission channel fails to transmit or accommodate all the required transactions (Joao et al., 2003) (Table 4). The complex and conventional grid infrastructure is one of the reasons for the low available transmission capacity that causes congestion in various developing countries like India (Ahmar et al., 2019).

Table 4. Congestion in the Electricity Transaction (CERC, 2017-18)

\begin{tabular}{|l|l|l|l|}
\hline \multirow{2}{*}{ Year } & \multicolumn{3}{|c|}{ Electricity (BU) } \\
\cline { 2 - 4 } & $\begin{array}{l}\text { Unconstrained } \\
\text { Cleared Volume }\end{array}$ & $\begin{array}{l}\text { Scheduled } \\
\text { Volume }\end{array}$ & $\begin{array}{l}\text { Uncleared Volume (due to } \\
\text { congestion) }\end{array}$ \\
\hline $2013-14$ & 35.62 & 30.03 & 5.59 \\
\hline $2014-15$ & 31.61 & 28.46 & 3.14 \\
\hline $2015-16$ & 36.36 & 34.20 & 2.16 \\
\hline $2016-17$ & 41.60 & 40.08 & 1.52 \\
\hline $2017-18$ & 45.86 & 45.65 & 0.21 \\
\hline
\end{tabular}




\section{Modified Formulation}

Hence, the study is concerned with the modification of parameters by replacing the installed power with the scheduled power for estimating market power. As there is always deviation in unconstrained cleared volume and actual cleared or scheduled volume, deviation arises due to the volume of electricity that could not be cleared because of congestion in the power exchange. This paper proposes to determine the actual market power using the scheduled volume instead of the unconstrained cleared volume.

$$
\begin{aligned}
& ¥_{\text {cong }}=\alpha_{\text {ucv }}-\beta_{\mathrm{s}} \\
& \beta_{\mathrm{s}}=\alpha_{\mathrm{ucv}}-¥_{\text {cong }}
\end{aligned}
$$

where aucv $=$ unconstrained cleared volume.

$¥$ cong = uncleared volume of electricity due to congestion

$\beta \mathrm{s}=$ scheduled or actual cleared volume.

Hence, the market power is calculated by using the HHI index from the shares of each firm. Shares are considered from the scheduled power of the firm excluding congestion as per modification. Then the modified HHI becomes-

$$
\text { HHI modified }=\sum_{i=1}^{n} p_{i}^{2}
$$

Similarly, modified concentration ratio becomes-

$$
\begin{aligned}
& \text { CR4modified }=\sum_{i=1}^{4} p_{i} \\
& \text { CR8modified }=\sum_{i=1}^{8} p_{i}
\end{aligned}
$$

where pi is the share of ith firm taken from scheduled power

The actual volume or scheduled power that gives the authentic value of its share in the power market is used to calculate the true market power.

\section{Analysis of Some Developed Power Markets}

In this section, various developed power markets and their trading platforms (PJM and Nord Pool) have been discussed.

\subsection{US Power Market}

U.S power market is a very competitive market and it offers easy participation of sellers in the power market. Its HHI index is less than 0.15 , this signifies there is no such firm exists in the power market, which controls the prices of electricity. The installed capacity of the largest generators has a share of less than $4 \%$ in the country's total installed capacity (Xue et al., 2018). PJM serves as an electricity trading platform in the US just like IEX promotes transparent electricity trading in India. In PJM the participation is compulsory for the day-ahead market and the quantity of bid can be changed till gate closure. According to the report published by FERC on the '2018 State of the Markets Report 2018' America has a total installed power capacity of 1194.78 GW.

\subsection{Nord Pool Power Market}

Nord pool was established in 1991 for electricity trading among Nordic countries. It offers participation in the voluntary market as well as market adjustment. The European power market has high competition compared with the power market of other countries. The price of electricity is decided according to zone wise demand similar to IEX. Most customers have open access to the transmission and distribution grids and furthermore, trading of electricity provides numerous options for the retailers to the customers(Morey et al., 2016). In 2013, the total installed capacity for power generation in the Nordic region was 103.313 MW(Nordic Market Report, 2014). The Nordic electricity market consists of wholesale electricity market and a retail electricity market. In Nomadic countries, about 50\% of energy production is mainly from hydropower.

\section{Conclusion}

This paper presents an analysis of the power market and modification of parameters used for estimating market power. HHI index and Concentration ratios (CR4, CR8) are calculated for the Indian power market. The results of this paper are useful to study the dynamic nature of market power and hence, in future this modified formulation would be beneficial to evaluate the actual market power. Power markets and various existing market structures were also part of our discussion. In addition to this, various developed power markets of the world have been examined. 


\section{References}

Ahmad F., Alam M.S., 2019, Assessment of power exchange based electricity market in India. Energy Strategy Reviews, Vol. 23, pp. 163-177, January.

An MHRD Project National Mission on Education through ICT (NME-ICT), Paper: Managerial Economics Module: 18 Market Power and Market Structure, Accessed: https://epgp.inflibnet.ac.in/Home/ViewSubject?catid=23

Asgari M. H. and Monsef H., 2008, Assessment the potential of suppliers to exercise market power in Reactive Power markets, 2008 IEEE Canada Electric Power Conference, Vancouver, BC, pp. 1-7.

Central Electricity Regulatory Commission, Report on Short-term Power Market in India: 2017-18, Accessed: www.cercind.gov.in/2018/MMC/AR18.pdf, pp. 46, 2017-18.

Central Electricity Regulatory Commission- Report on Short-term Power Market in India: 2017-18 Accessed: www.cercind.gov.in/2018/MMC/AR18.pdf, p. 13, 2017-18.

Central Electricity Regulatory Commission, Report on Short-term Power Market in India: 2017-18, Accessed: www.cercind.gov.in/2018/MMC/AR18.pdf, p. 14, 2017-18.

Central Electricity Regulatory Commission- Report on Short-term Power Market in India: 2017-18, Accessed: www.cercind.gov.in/2018/MMC/AR18.pdf, p.25, 2017-2018.

Central Electricity Regulatory Commission- Report on Short-term Power Market in India: 2017-18, Accessed: www.cercind.gov.in/2018/MMC/AR18.pdf, p.25, 2017-2018.

Central Electricity Regulatory Commision. Accessed: www.cercind.gov.in, pp.17-31, 2017-18

Central Electricity Authority, Executive Summary on Power Sector, Accessed: http://www.cea.nic.in/reports/monthly/executivesummary/2019/exe_summary-06.pdf, p. 8, June-2019.

Central Electricity Regulatory Commission, Report on Short-term Power Market in India: 2017-18, Accessed: www.cercind.gov.in/2018/MMC/AR18.pdf, p. 4, 2017-18.

Central Electricity Regulatory Commission, Report on Short-term Power Market in India: 2017-18, Accessed: www.cercind.gov.in/2018/MMC/AR18.pdf, pp. 24-25, 2017-18.

Chernenko N., 2015, Market power issues in the reformed Russian electricity supply industry, Energy Economics, June.

David A.K. and Wen F., 2001, Market power in electricity supply, in IEEE Transactions on Energy Conversion, Vol. 16, No. 4, pp.352-360, Dec.

Government of India-Ministry of Power, Power Sector at a Glance ALL INDIA", Accessed: https://powermin.nic.in/en/content/power-sector-glance-all-india, 31 May 2019.

João, M. \& Gonçalves, D. \& Vale, Z., 2003, Competitive power market analysis - Evaluation of market power due to congestion effects on transmission system, Renewable Energy and Power Quality Journal,. 1. 10.24084/repqj01.366.

Khan M. T., Siddiqui A. S., Sarwar M., and Iqbal F., 2015, Mitigation of market power in deregulated power system using Nash Equilibrium, 2015 Annual IEEE India Conference (INDICON), New Delhi, pp. 1-5.

Morey M. J., and Kirsch L.D., 2016, Retail choice in electricity: what have we learned in 20 years? Technical Report, Feb.

Nordic Market Report 2014, Development in the Nordic electricity market, Accessed: www.nordicenergyregulators.org/wpcontent/uploads/2014/06/Nordic-Market-Report-2014.pdf, pp. 52-53

Rhoades, 1995, Review of industrial organiziation, Kluwer Academic Publishers, Dordecht, Netherlands, Vol. 21, pp 9-43.

Twomey, P., Green, R., Neuhoff, K., Newbery, 2004, A review of the monitoring of market power. Cambridge Working Papers in Economics.

Xue X., Wang X., Liu D., Guo J., Li L. and Li X., 2018, The enlightenment of foreign power market reform experience to china's power market construction, 2018 2nd IEEE Conference on Energy Internet and Energy System Integration (EI2), Beijing, pp. 13.

Yang J. and Jordan G., 2000, System dynamic index for market power mitigation in the restructuring electricity industry, 2000 Power Engineering Society Summer Meeting (Cat. No.00CH37134), Seattle, WA, Vol. 4, pp. 2217-2222.

Zammit M. B., 1999, Security in deregulated power systems: Market design and decision analysis, Ph.D. dissertation, University of Sydney, Australia.

\section{Biographical notes}

Prof. Asheesh K Singh (M'08, SM'13) is associated with the Electrical Engineering Department of MNNIT Allahabad as a faculty member since 1995, where he is Professor and head, presently. He did his graduation in Electrical Engineering from HBTI Kanpur in 1991, post-graduation from REC Kurukshetra in 1994, and obtained a Ph.D. degree from IIT Roorkee in 2007. His research interests are smart grids, distributed generation, power quality, Microgrid, renewable energy sources, and E-Mobility. His active participation in IEEE activities highlights his professional service. He is Senior Member of IEEE, and Life Member of Indian Society for Technical Educational (ISTE). As IEEE member of Uttar Pradesh Section, he volunteered as Chapter Coordinator for Joint Chapter of Industrial Electronics, Power Electronics \& Control System, Convener for Educational Activities Committee in 2013, Secretary of PES Chapter in 2014, Convener for Special Interest Group on Humanitarian Technology (SIGHT) in 2015 and 2016, Vice-Chairperson in 2017 and 2018; and Section Chair in 2019 and 2020. Furthermore, he has introduced 04 weeks Summer Internship Program in Electrical Engineering Department at MNNIT Allahabad, organizing annually, since 2016. It is a coordinated activity of MNNIT Allahabad with technical sponsorship of the IEEE UP Section. 
Dr. Prabhakar Tiwar is currently Associate Professor at Department of Electrical Engineering, Madan Mohan Malaviya University of Technology. Before joining MMMUT he was Professor \& Head at Krishna Institute of Engineering Technology, Delhi. He has more than 20 journal publications in reputed journals and he is also currently Secretary of IEEE UP Section. He has more than 18 years of teaching experience and his area of interest include Distributed Generation, Electrical Power Engineering, Power System Analysis, Power Market Restructuring, Power System Simulation and Modeling. He is also recipient of Outstanding Volunteer Award IEEE UP Section.

Aniket Raj \& Utkarsh Gupta are currently B-Tech final-year students of Madan Mohan Malaviya University of Technology, Gorakhpur(U.P.) with majors Electrical Engineering. 